\title{
Dispersion and Rheo-optical Properties of the Components in Mechanically Blended Films of Polyethylene and Polypropylene
}

by

The Late Takashi Oda, Matsuo Maeda, Sadao HibI,

Hiroshi Motogami and Kenji Ando

(Nagoya Institute of Technology, Gokiso, Showa-ku, Nagoya)

The difference between the dispersion of the components in two mechanically blended films of polyethylene and polypropylene was investigated by means of optical microscopic and mechanical tests. The films were cast from melts at $230^{\circ}$ and $270^{\circ} \mathrm{G}$. The results show that a film cast at $270^{\circ} \mathrm{C}$ has better continuity than a film cast at $230^{\circ} \mathrm{C}$, both having the same composition.

Furthermore, the results obtained by the simultaneous measurement of creep and birefringence show that the PE phase in the film of the blends deforms easier than the PP phase.

\section{ポリエチレンーポリプロピレン混合物皮膜における 各成分の混合状態と流動光学的性質}

\author{
故 小田 隆・前田松夫 ・日比貞雄 - 元神弘史 ・安藤健次 $*$
}

（原稿受理：1974年 1月18日）

I 緒言

前報におろいてポリエチレン一ポリプロピレン機械混合皮膜にお ける各成分の混合状態を密度測定, 光散乱, 偏光顕微鏡, および 複屈折等の手段により検討した ${ }^{1)}$. 本報告においては成膜条件を 異にするととにより, 各成分の分散状態の差異を明らかにする. また少なくとも光学顕微鏡下で明らかに混合状態の異なる皮膜を 製作し, それらの力学的性質の差異から各成分の連続性を検討す る.さらに各成分が比較的微視的に混合した系列について, クリ ープと複屈折を組合わせた, いわゆる流動光学的方法により, 各 成分の変形性を検討する.

\section{2 実験}

\section{$2 \cdot 1$ 試料}

低密度ポリエチレン（三菱油化製，PE），およびアイソタクチ ックポリプロピレン（三井東圧化学製，PP)，を原試料とした。 PE および PP を各混合分率に混合した後ヘンシルミキサで混合 し, DSM を用いて溶融混合し, 水中に吐出させ, 切断機でチッ

\footnotetext{
* 名古屋工業大学 名古屋市昭和区御器所
}

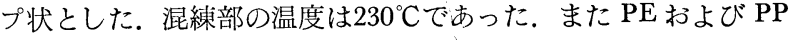
についても同じ熱および機械履歷を与えた。

製膜は実験用熱プレスにより，PE，PP，および混合物を $230^{\circ} \mathrm{C}$ で10分間溶融し,さらに加圧状態で 2 分間放置した後 $20^{\circ} \mathrm{C}$ の水中 で急冷した. ての系列を $230(i)(i=1,2,3, \cdots \cdots 9)$ と名付けた.

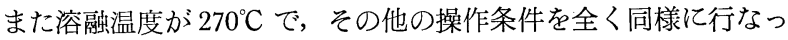
て作製した皮膜の系列を 270(i) $(i=1,2, \cdots \cdots 9)$ とした. 試料 番号 (i) と各混合分率の関係を Table 1 亿示した。

Table 1. The Blending Ratio of the Samples.

\begin{tabular}{c|rcccccccc}
\hline No. & 1 & 2 & 3 & 4 & 5 & 6 & 7 & 8 & 9 \\
\hline $\mathrm{PE}(\%)$ & 100 & 87.5 & 75.0 & 62.5 & 50.0 & 37.5 & 25.0 & 12.5 & 0 \\
$\mathrm{PP}(\%)$ & 0 & 12.5 & 25.0 & 37.5 & 50.0 & 62.5 & 75.0 & 87.5 & 100
\end{tabular}

\section{$2 \cdot 2$ 测 定}

$2 \cdot 2 \cdot 1$ 光学顕微鏡 試料皮膜から薄片を切り出し, エチルベ ンゼンを浸せき液としてプレパラート上に置き, 偏光顕微鏡の直 交ニコル下で観察した。

$2 \cdot 2 \cdot 2$ 密度 エチルアルコール一水系の密度勾配管を用いて $25^{\circ} \mathrm{C}$ で測定した. 


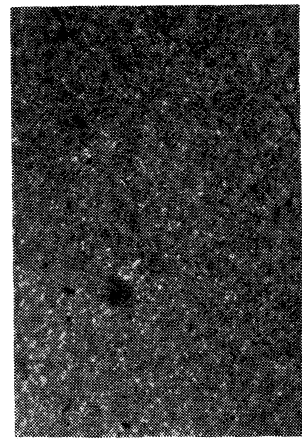

$230^{\circ} \mathrm{C}$
$\mathrm{PE} / \mathrm{PP}$ (w.f.) $100 / 0$

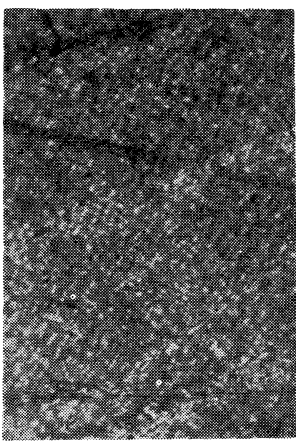

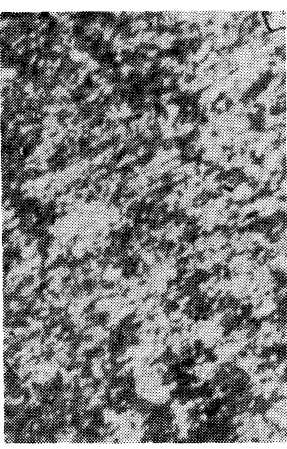

$75 / 25$

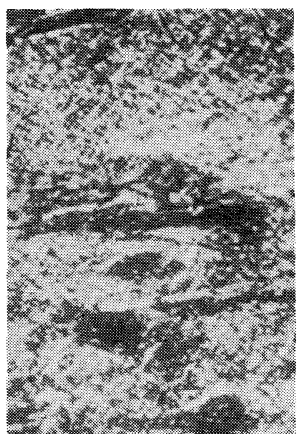

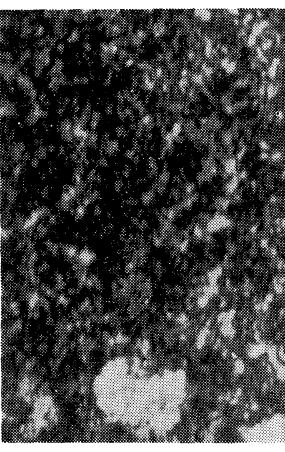

$50 / 50$

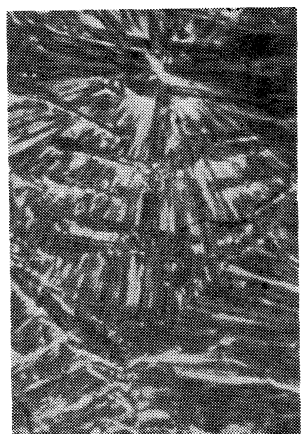

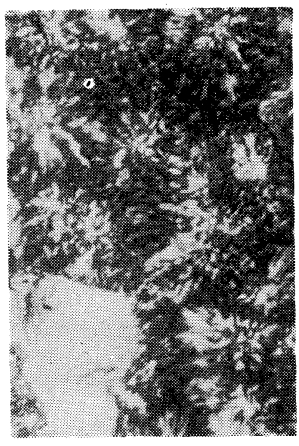

$25 / 75$

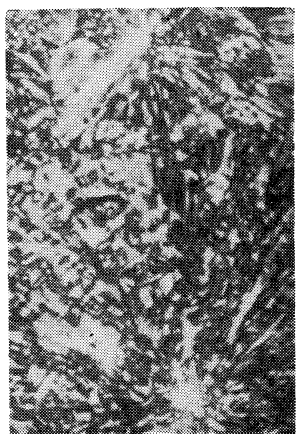

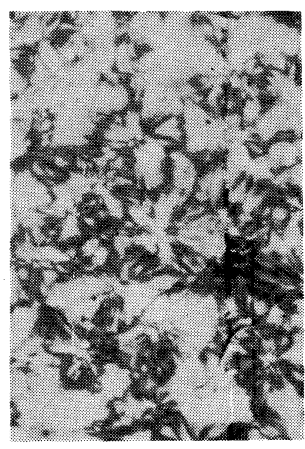

$0 / 100$

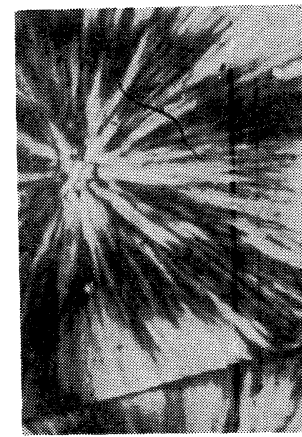

Fig. 1 Polraized micrographs showing the changes in dispersion and superstructure of films of PE, PP, and PE-PP mechanical blends cast at $230^{\circ}$ and $270^{\circ} \mathrm{C}$.

$2 \cdot 2 \cdot 3$ 動的弾性率 バイブロン DDV II 型（東洋測器製）

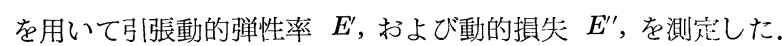
測定温度は $-120^{\circ} \sim 130^{\circ} \mathrm{C}$ の範国であった.

$2 \cdot 2 \cdot 4$ 定速伸長テンシロンを用いて室温で $0.5 \% / \mathrm{min}$ および $50 \% / \mathrm{min}$ の定速で一軸伸長を行なった. 試料皮膜の厚さは約 0.3 $\mathrm{mm}$ であり, 巾 $5 \mathrm{~mm}$, 長さ $50 \mathrm{~mm}$ のリボン状に切断したものを 用いた。

$2 \cdot 2 \cdot 5$ クリープー複屈折同時測定 通常のクリープ測定装置 と複屈折測定装置と組合わせて同時測定を行なった。複屈折はバ ビネコンペンヒータを用いて直読した。

\section{3 結果および考察}

Fig. 1 亿 $230^{\circ} \mathrm{C}$ おび $270^{\circ} \mathrm{C}$ で溶融して製膜した混合分率の異 なる皮膜の偏光顕微鏡写真の比較を示す. $230^{\circ} \mathrm{C}$ で溶融した系列 については，いずれの混合分率の皮膜においても相分離は明確で ない, 一方 $270^{\circ} \mathrm{C}$ で溶融した系列については, 各混合物皮膜にお いていずれも $\mathrm{PP}$ 相と $\mathrm{PE}$ 相とに分離している. $230^{\circ} \mathrm{C} て ゙$ 溶融し た系列に一いては少なくとも $\mathrm{PE} / \mathrm{PP}=50 / 50,25 / 75$ および $0 / 100$ （5，7および $9 ）$ においてほほ $100 \mu$ の直径の球晶が観察され る。また $\mathrm{PE}$ 相についても $\mathrm{Hv}$ 光散乱像が明確な四葉クロ一バ 状像を与えるととから球晶を形成していることが確喼され の直径は散乱強度極大から算出 ${ }^{2)}$ すると数低であ.したがって PP 球晶中に PE 相が分散し, 球晶を形成しているものと考光ら れる. $270^{\circ} \mathrm{C}$ で溶融した系列では $\mathrm{PE} / \mathrm{PP}=50 / 50 ， 25 / 75$ ，および 0/100 亿おいて発達した PP 球晶が確認され，その直径は 500〜 $600 \mu$ である. また PE 相は完全に相分離しており， Hv 光散乱 像より直径数 $\mu$ の球晶を形成しているととが認められる.
密度測定の結果は, $230^{\circ} \mathrm{C} て ゙$ 溶融した系列において PE は 0.926 $\mathrm{gr} / \mathrm{cm}^{3}$ であり，PP は $0.912 \mathrm{gr} / \mathrm{cm}^{3}$ であった。 また混合物皮膜 の密度は, 両成分の体積分率に依存してほぼ両成分の加算性が成 立する。一方 $270^{\circ} \mathrm{C} て ゙$ 溶融した系列は, $230^{\circ} \mathrm{C} の$ 系列に比べて若干 高い密度を示す ${ }^{3)}$. 乙れは相分離, 分子量分別および不純物分列 等の結晶化において結晶性を增加させる作用のあるととを暗示し ていよう。

上記のように，明らかに PE および PP の混合状態が異なる 場合，それらの力学的性質がいかに異なるかを梌㑏した． Fig. 2 亿混合分率の異なる上記 2 系列の皮膜の動的弾性率 $E^{\prime}$ および動 的損失 $E^{\prime \prime}$ の温度変化を示す. PE および PP の $E^{\prime}$ および $E^{\prime \prime}$

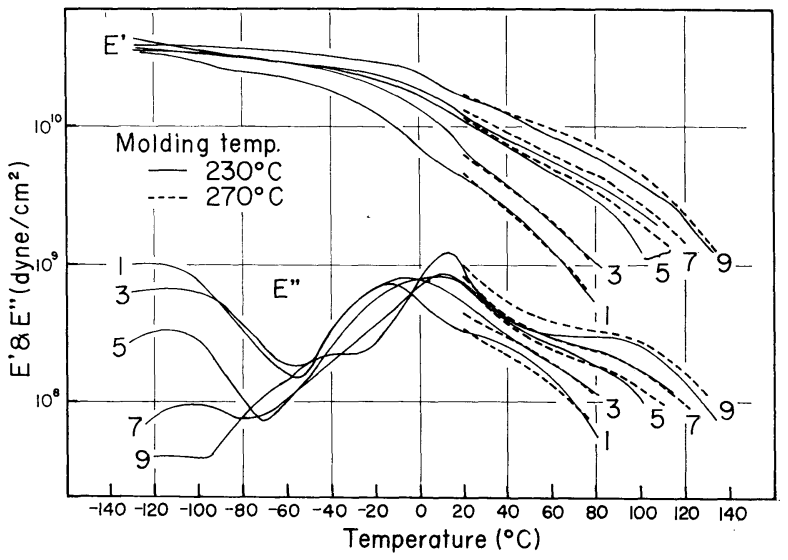

Fig. 2 Dynamic modulus $E^{\prime}$ and loss modulus $E^{\prime \prime}$ vs. temperature for films of PE, PP, and PE-PP mechanical blends cast at $230^{\circ}$ and $270^{\circ} \mathrm{C}$. 
の温度変化に関しては従来の結果 ${ }^{4)}$ と差がないので詳述しない. また混合物皮膜の $E^{\prime}$ および $E^{\prime \prime}$ は，上記 2 系列ともに，PE お よび PP の混合分率に依存して系統的に変化している。すなわち $E^{\prime}$ の温度依存性は, PP の分率が大きいほぞ各温度で高い值を示 す。また $E^{\prime \prime}$ の温度依存性および $E^{\prime \prime}{ }_{\max }$ の位置は，それぞれ従 来の報告とほぼ同じである。しかしながら上記二系列の同組成の 皮膜の $E^{\prime}$ を比較すると, 特に(5)および(7)について $270^{\circ} \mathrm{C}$ 溶融物 の方が高い值を示し, かつより高温まで安定であることが明らか である. てれは溶融後の固化過程において $270^{\circ} \mathrm{C}$ 溶融物の方がよ り相分離が起りやすく, かつ PP 相が連続相になりやすいてとを 暗示していよう. 以上の結果は, 混合状態の差異が微小変形領域 では弾性率等の巨視的な性質には顕著な差として現われないとと を示している.

つぎに混合状態の差異による皮膜の延伸性の差異を検討するた め, 定速一軸延伸を行なった. Fig. 3 亿一例として $50 \% / \mathrm{min}$

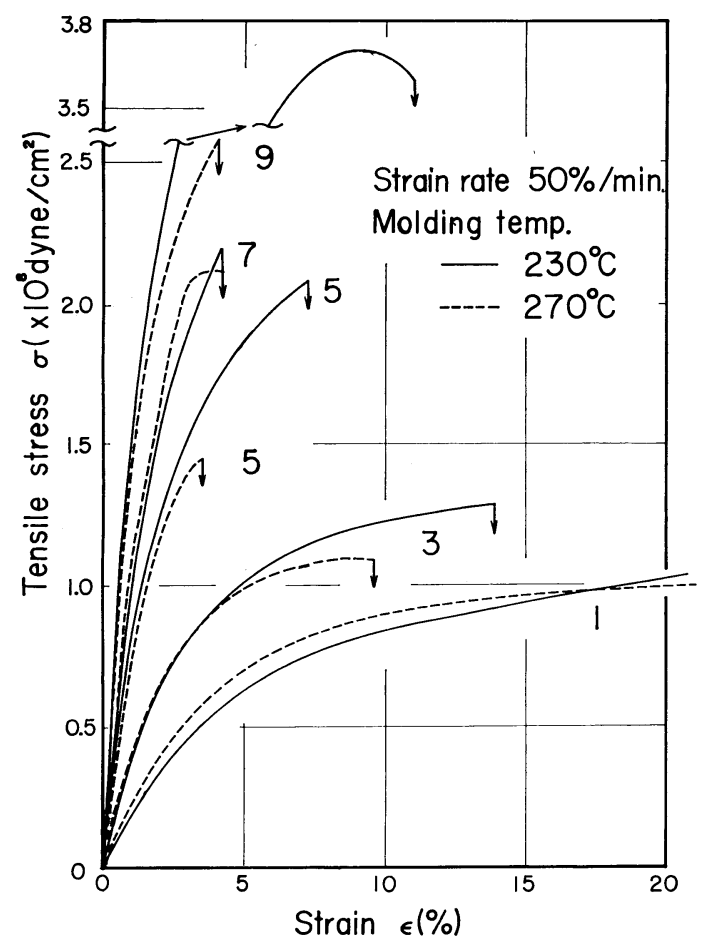

Fig. 3 Stress-strain curves for films of PE, PP, and PEPP mechanical blends stretched at a constant strain of $50 \% / \mathrm{min}$.

の定速で一軸延伸を行なったものを比較して示した. 図から明ら かなように, 組成が同じである場合には, 応力一歪曲線の形にほ とんぞ差がないが, 破壊伸びに大きな差が現われている.特にPP

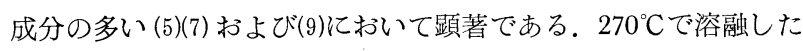
系列では, 相分離および分子量分別等により PP 相が完全度の高 い球晶を形成し, しかも連続性が高くなり, PP 相のぜい性が顕 著に現われた結果によるものと考えられる。また $230^{\circ} \mathrm{C}$ 溶融物に おいては(7)の破壊伸びが特に小さくなっており，PEが混入され たととによる相分離および PP 相のぜい性が合わさった結果によ ると考えられる.

混合物の延伸において PE および PP がどのように寄与するか を検討するため, $230^{\circ} \mathrm{C}$ で溶融した系列についてクリープおよび

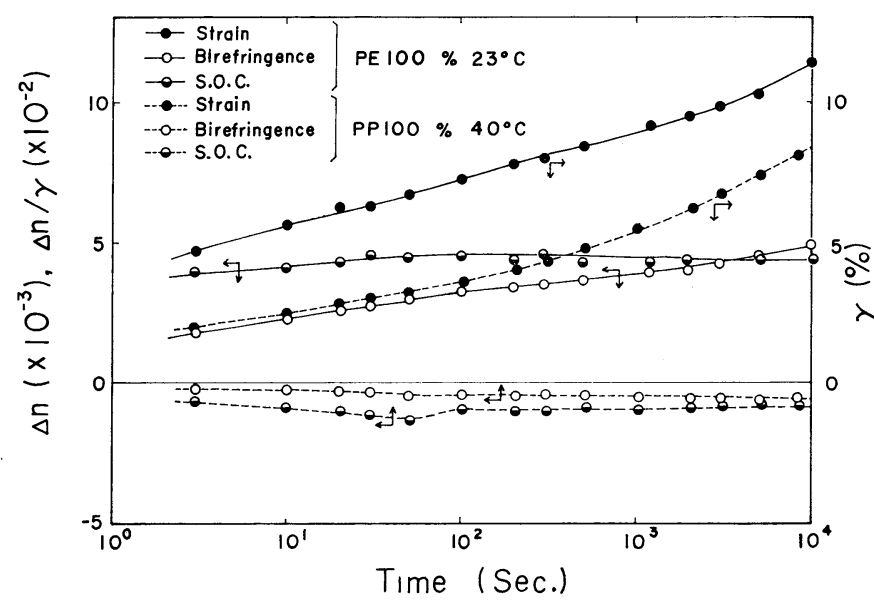

Fig. 4 Original curves of strain, birefringence, and strain-optical coefficient vs. logarithmic time.

機屈折を同時測定した. Fig. 4 亿 PE および PP そ対する歪 $\gamma$, 複屈折 $\Delta n$, および歪一光学係数 $\left(\frac{\Delta n}{\gamma}\right)$ の時間依存性の一例

を示す. 複屈折の測定にはバビネコンペンセータを用いて直読式 で行なったため, 延伸速度が比較的おそい領域である，本実験範 囲では複屈折值がクリープの荷重依存性を示さない.すなわち複 屈折は歪にのみ依存する.したがって Fig. 4 亿示された歪光学 係数 (S.O.C) は物質の特徴的な量として意味をもつ. Fig. 4 亿 おいて PE の S.O.C は丕10\%までほぼ同值を示し, PP では歪 $3 \%$ 付近に極小值を示すが，5～10\%まではほぼ同值を示す．乙 れらの特徴は PE および PP について室温以上融点付近までほ ぼ同じである．また混合分率の異なる各皮膜についても同じ特徴 の結果が得られたので，以下ではすべて歪一光学係数 (S.O.G) で整理した。

Fig. 5 そ $\mathrm{PE}, \mathrm{PP}$ および $\mathrm{PE} / \mathrm{PP}=50 / 50$ の歪一光学係数の温

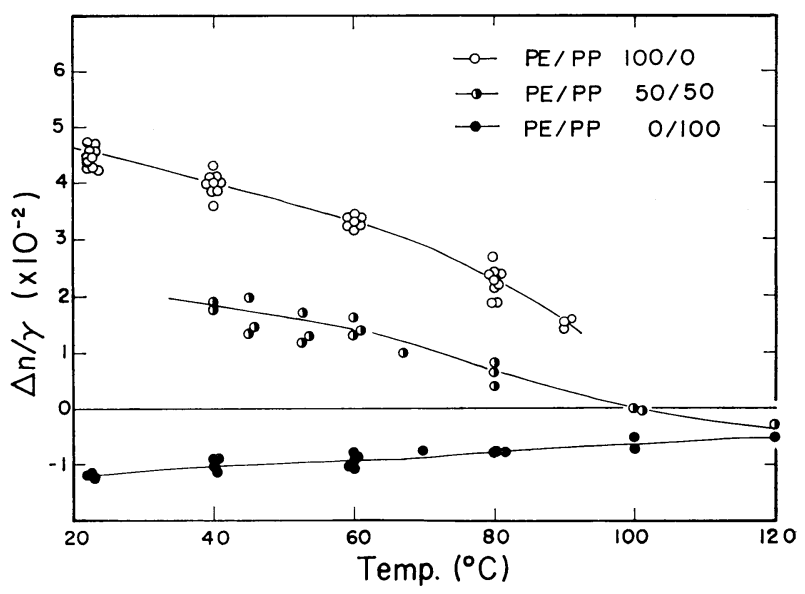

Fig. 5 Temperature dependence of strain-optical coefficients for films of $\mathrm{PE}, \mathrm{PP}$, and $\mathrm{PE} / \mathrm{PP}=50 / 50$.

度依存性を示す，歪一光学係数をより正確に比較するために, 歪 $6 \%$ おける歪一光学係数で比較した，PE は比較的温度依存性 が顕著であり，PE の結晶化度の温度依存性および結晶の軟化に 依存しているものと考朰れる.PP は絶対值の小さいてともあ るが, 結晶化度の低下および結晶の軟化が比較的高温にあるため, 


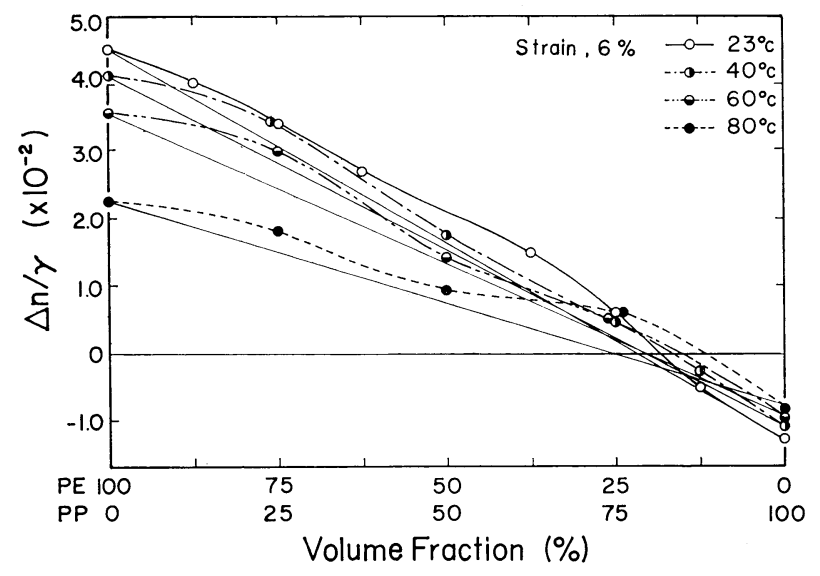

Fig. 6 Changes in total birefringence with volume fraction of $\mathrm{PP}$ at $23^{\circ}, 40^{\circ}, 60^{\circ}$, and $80^{\circ} \mathrm{C}$.

測定の範囲では変化が少ないものと考えられる．また $\mathrm{PE} / \mathrm{PP}=$ 50/50 の皮膜は主として PE の影響をうけ, 温度上昇とともに歪 一光学係数が低下すると考元られる.
Fig. 6 には種々の温度における歪一光学係数の混合分率依存 性を示した. 各測定温度で PE および PP の歪-光学係数を結 んだ直線（細線）は PE および PP の歪-光学係数の各成分の 加算性を示す。しかしながら各測定温度における実測值はすべて 直線の上部にプロットされる．乙れは各混合物皮膜の延伸に際し てPE 相が PP 相より大きく変形するてとを示している，てれら の結果は，丕が大きくなるとさらに顕著になる ${ }^{5)}$.

\section{4 文献}

1）前田松夫, 小田隆, 日比貞雄, 牧野正三, 浅野雅克, 安藤健 次, 高化, 30, 282 (2973).

2) Samuels, R.J., J. Polymer Sci., C, 13, 37 (1966).

3）小田隆, 前田松夫, 日比貞雄, 元神弘史, 安藤健次, 第22回 レオロジー討論会要旨集, pp 162 (1973).

4）例えば浅田忠裕, 深尾年樹, 田中皓, 小野木重治, 材料, 17, 59 (1968).

5）小田隆, 日比貞雄, 前田松夫, 牧野正三, 安藤健次, 浅野雅 克，高化，30，288 (1973). 